\title{
Exploring Design Needs of Wifi-Marketing as Promotional Strategy for Mall Industry
}

\begin{abstract}
Nalal Muna ${ }^{1}$, Fajria Fatmasari², Aji Kresno Murti ${ }^{3}$
${ }^{1}$ Manajemen Pemasaran Industri Elektronika, Politeknik APP Jakarta, Jakarta, Indonesia

${ }^{2}$ Manajemen Pemasaran Industri Elektronika, Politeknik APP Jakarta, Jakarta, Indonesia

${ }^{3}$ Manajemen Pemasaran Industri Elektronika, Politeknik APP Jakarta, Jakarta, Indonesia

nalal@kemenperin.go.id (Nalal Muna), fajria@kemenperin.go.id (Fajria Fatmasari), aji.kresno@kemenperin.go.id (Aji Kresno Murti)

Abstract Jakarta is one of mall paradise in Indonesia. The emergent of middle class economy has shifted consumer behavior in visiting Mall. Nowadays, people visit mall for various reasons such as hangout with friends, meeting with client, window shopping and many more. Moreover, Wifi Marketing is new trend in marketing innovation. It is one of competitive advantage in attracting more visitors. However, More visitors don't guarantee the increase sales of tenants in Mall. Promotions are needed to help tenants in reaching out mall visitors through wifi-marketing. The purpose of this research is to explore the design needs of Wifi-marketing as cutting edge technology to maximize promotional strategy for Mall business. This is qualitative research in which data is collected through observation and in-depth interview with 8 informants (3 tenants and 5 visitors of shopping mall). The findings showed positive technological readiness towards wifi-marketing which can be interpreted from their optimism, innovativeness, discomfort and insecurity. Optimism and innovativeness become the drivers of wifi-marketing since it showed users' likelihood to adopt wifi for promotional purpose. However, discomfort and insecurity become the constraints for wifi-marketing in terms of privacy issue. Using design ethnography, the design of wifi-marketing welcome page should meet with visitors's needs such as information about mall directory, promotions and special offerings, new tenants information, restaurant recommendation, and customer service support.
\end{abstract}

\section{Keywords wifi, marketing, promotions, mall, design, ethnography}

\section{Introduction}

By 2016, 76 out of 250 malls in Indonesia are located in Jakarta. Although shopping malls contribute to national economic growth, over populated malls in Jakarta caused several issues related to traffic jam, green space and consumerism. Former governor of Jakarta, Joko Widodo, addressed formal gubernatorial decree in the moratoium of mall construction in a bid to ease trafic and improve city planning efforts [1]. It's been challenging policy for shopping mall industry in Indonesia. Based on Cushman \& Wakefield, real estate consultant, reported that Jakarta occupied $70.9 \%$ of retail supply. However, it decreased by $65.1 \%$ after the moratorium. Moreover, based on the demand, the occupancy rate of retail market drop to $0.3 \%$ per-quartal or $1.1 \%$ per-year [2].

The Colliers International stated that shopping mall performance in Jakarta shows stagnant growth [3]. The growth of shopping malls are forced by the domination of restaurant and food stalls at mall area. The growth of information and communication technology has tremendous impact on people's lifestyle. Moreover, the increase of middle class in Indonesia has become potential market for shopping mall. The middle class is defined as households with expenditure between $\$ 2$ and $\$ 13$ per person (in 2005 consumption PPP dollars) [4].

The number of middle class in Indonesia has reached $70 \%$ of Indonesia's population on 2015 [5]. The growing number of Indonesia's middle income segment has shifted the way they spend their income and their lifestyle. Especially regarding to their spending habits at shopping malls, people nowadays has several reasons on visiting shopping malls. Nowadays, people prefers to solely hangout with their family or friends, meeting with client or colleagues, windows shopping and also considered shopping malls as recreational spot. Moreover, people in middle class income are more affluence and has less price sensitivity [6].

Unfortunately, the trend shows that people swarming shopping mall specifically at dining spot rather than for shopping purpose. Consumers begin to place greater empahsis on food and beverages at the mall. Online shopping has become prevailing trend in Indonesia. Based on survey by Nielsen [7], the increase of smartphone users and cheaper data access have triggered on the increase of online shopping in Indonesia from $9.4 \%$ in 2013 to $23 \%$ in 2016. Although it's still in early stage, it shows significant impact on people's shopping behavior. Fashion products dominate by $68 \%$, travel (35\%) and cosmetics (29\%). 
The emergent of middle class income and digital consumer become more challenging for mall industry. Especially for mall management. Das and Varshneya [8] suggested to point out mall atmospherics to capture consumers' excitement and value perceptions. There are several research and innovation on technology advancement [9][10][11] for mall industry that developed Bluetooth beacon technology and GPS-based to map for products at mall. Those technology failed to meet the needs for mall regarding to the high investment and lack of improvement.

However, no study so far has captured wifi as technological advancement for shopping mall. This research is an attempt to fill the void. This research extends the existing literature in providing integrated concept of Wifi and Marketing. The objective of this paper is to explore the needs and challenges for leveraging wifi on shopping mall for promotional purpose.

\section{Theoretical Background}

\subsection{Wifi Marketing}

Wireless communication has become a significant growth area in recent years. According to one projection, 1.1 billion users of wireless devices include some 90 million that are Internet-ready; and half of the Internet traffic will be wireless [12].

Wireless Technology provides the potential for every marketing and management professional to communicate everywhere and everyplace twenty-four hour a day. Wireless access to the Internet is expanding rapidly. Kiplinger Letter stated that wireless access exists at airports, hotels and specialty shops such as Starbucks; it is expanding to gas stations such as Conoco and Circle K; and a - new AT\&T - Intel IBM hot - spot venture will blanket 50 top markets [13] (Dec. 6, 2002). Communication News reports some significant finding among businesses with wireless usage [14](April, 2002):
a) sales increases of $10 \%$ to $20 \%$
b) reduced customer wait times of as much as $80 \%$
c) increases in service calls up to $32 \%$
d) service-call responsiveness improvements of $7 \%$

Although the longest payback period found was 30 months, most businesses achieved payback in just a few months [15].

One of the newest developments in wireless technology is wireless fidelity, commonly called -Wi-Fi to create a - hot spot. According to Munro [16], a Wi-Fi device (access point) consists of an electronics component with a transmitting antenna; the device uses a weak signal that uses part of the electromagnetic spectrum not requiring approval by the FCC.

One of the latest way of marketing is through the internet or it may be called internet marketing. By this way, it allows consumers and marketer to interact more personal. It introduces WiFi marketing as one of the newest, innovative, and effective ways to advertise. It is about communicating a message or content directly to potential customers or users near the point of emission [17]. Technically, it is the creation of a coverage area based on WiFi technology that enables anyone with a mobile device (laptops, notebooks, smartphones, tablets, etc.) equipped with WiFi technology to connect to and access the services or content that has been made available. Thus marketer are allowed to upload and put advertising of their business onto the opening page, or in the web as the term and condition applied.

Considering about internet marketing, it encourages us to be closer to some terms. They are (i) Banners, the most familiar form of advertising on web is banner ads. Banner ads generally used for creating awareness, entering viewers into contests and sweepstakes. (ii) Sponsorships, they are divided in regular sponsorships where a company pays to sponsor a section of a site and another is the content sponsorship, in which sponsor not only provides money in return for name association but participates in providing the content itself; (iii) Pop-Ups/Pop-Under, the ad which is almost similar to banner ads but here user will see some ads when he/she access some sites. Pop-Under are ads appear underneath the web page and visible when user leaves the sites. (iv). Interstitials are ads that appear on screen while user waiting for site's content to download. (v) Push Technologies, Marketers use web casting or push technologies for dispatch web pages and news updates and video geared to specific audiences or individuals. Links: Links appears when users search specific links then automatically provide users additional links or related topics. (vi.) Paid Search Marketers, that is paid for each consumer's clicks on their ads or links from a search engine page. (vii). Behavioural Targeting Marketers use behavioural targeting advertising for target consumers through their web site surfing behaviours. (viii) Contextual Ads Advertisers who target their ads based on the content of the web page are using. (ix) Rich Media that is a broad range of interactive digital that exhibit dynamic motion, taking advantage of enhanced sensory features such as video, audio and animation. Online commercials, video on demand and webisodes are the main types of rich media. The increased penetration of broadband into households has increased the attention given to streaming video [18].

Nonetheless, the wireless world of electronics may not ever measure up to a customer's real-world experience. The customer is ever-changing. Each company needs to understand the implications of every wireless technology and what it means to the company in terms of developing the customer's relationship [19].

\subsection{Promotional Strategy}

There is a view of marketing promotion strategy as the design and management of a marketing sub-system for the purpose of informing and persuading present and potential customers and clients. The promotional elements are organic, for example, advertising can be seen as the taking of the horse to the stream while personal selling is forcing the horse to drink some water [20]. It means that company should be delivering messages to consumers through many ways. The way of delivering message can be through advertising, personal selling, publicity, direct marketing, and sales promotion. Promotion will spread out about all information such as product, price, brand, and may also company. 
Promotional strategies are the means by which marketers communicate important information about their products and persuade consumers to purchase them. Key activities in designing and managing promotional strategies are as follows [21]:

a) identify the target market (receiver);

b) determine the promotional objectives (desired consumer response);

c) develop the promotional strategy (message, source, medium);

d) implement the promotional strategy;

e) evaluate the effects of the promotional strategy (feedback).

According to Adefulu [22], promotional strategy can impact to organization and their profitability. The study therefore recommends that organization in their promotional strategy plan should identify which of the promotional tools the customers responds to favourably and ensures resources are concentrated on sales promotion, advertising, and publicity to maximize returns on promotional strategy expenditures. The use of the promotional strategy tools should be determined by the promotional objectives to be achieved, market share or profitability [23]. Furthermore, promotional budgets should be enhanced to further strengthen the impact of the adopted tools on market share and profitability.

\subsection{Technology Readiness Theory}

Organisations adopt new technologies to improve the efficiency and effectiveness of various work processes. Unfortunately, many technology-based products and services never reach their full potential, and some are simply rejected [24]. Failed investments in technology may not only cause financial losses, but also lead to dissatisfaction among employees. Thus, it is important to adopt new technology to advance the system, even for marketing.

Parasuraman [25] developed technology readiness (TR) refers to people's propensity to embrace and use new technologies for accomplishing goals in home life and at work. Technology readiness comprises four dimension: optimism, innovativeness, discomfort, and insecurity. According to Erdog mus and Esen [26], those four traits used as measurement to assess readiness towards new technology. Optimism is a positive belief about technology to increase control, flexibility and efficiency. Meanwhile, innovativeness is a tendency to be the first using a new technology. Discomfort describes as a need for control and a sense of being overwhelmed. Regarding to insecurity, it described as distrusting feeling towards technology in terms of security and privacy reason.

Optimism and innovativeness are drivers for technology readiness meanwhile discomfort and insecurity are constraints that could lead to negative attitude towards adoption of new technology. [27]

\section{Research Methods}

This is qualitative research using observation and interview methodology to collect the data. To explore the design needs regarding to wifi marketing, in-depth interview is used to selected participants. The target population of the study is tenants and visitors of shopping mall at Jabodetabek (Jakarta, Bogor, Depok, Tangerang, Bekasi) area. In total, there are 8 participants consist of 5 visitors and 3 tenants.

Among these participants, 3 were men ad 5 were women whose ages ranged from 18-50 years old. Purposive sampling is used to determine the participants selection for this research. For mall visitors, all participants who used smartphone and experienced with wifi at the mall.

The interview is taken place for 30-60 minutes according to the participant's convenience. An interview is used to uncover greater insight or detailed information on probing the participants. In-depth interviews were therefore chosen in order to identify deeper attitude and behaviour towards wifi for promotional purposes in shopping mall.

The data is analysed using design ethnography study. This study is to ultimately understand more of the user's perception of the object, environment, system, or service the user is engaged with. Moreover, ethnography is used to develop a descriptive understanding of the lifeways of the participants studied. As Anderson (2003) stated that ethnography is the branch of anthropology that involves trying to understand how people live their live. [28]

The objective of this research is to explore the design need of wifi marketing as promotional purposes. Therefore, the data from interview will be used as an insight to develop wifi for promotional purposes. In regard to develop that technology, technology readiness theory is used to guide the probing process for the tenants and visitors. Technology readiness index (TRI) presents four constructs of technology belief that affect an individual's level of technology readiness which are optimism, innovativeness, discomfort and insecurity. [29]

Meanwhile, ethnography is relevant to analyse the design for several reasons: (1) to gain insight on the user's environment (2) to eliminate the designers' worldview (3) to optimize technologies even when there is uncertainty regarding use (4) to better understand the context of use (5) to provide more comprehensive picture of the technology for the user (6) to shift design from single-task focus in order to account for a more holistic understanding outside influences on the users.

\section{Result}

\subsection{Cultural Context of The Study}

Viswanathan et al. [30] stated that to derive meaning from the experience that informant described, it is important to understand the beliefs, values, and customs that guide and direct societal behaviour.

Based on the observation and interview, ethnography is used to explore the relationship between developing a descriptive understanding of human behaviour and designing artefacts that support the activities described. First part of the 
finding will describe the interpretation of wifi-marketing readiness of tenants and visitors. Therefore, the second part will explore the design needs of wifi-marketing at shopping mall.

The informants from this research are tenants and visitor of shopping mall since they will be the major end-customer for wifi marketing. Tenants chosen are middle-low mall such as Summarecon Mall Bekasi, Pasaraya Grande Blok M and Blok M Square Mall from various type of businesses.

Table 1. Demographic Characteristics of Tenants

\begin{tabular}{|l|l|l|l|l|}
\hline Informant & $\begin{array}{l}\text { Type of } \\
\text { Business }\end{array}$ & Sex & Age & Promotion Strategy \\
\hline Dyca & Food & M & 29 & $\begin{array}{l}\text { Social Media (Face- } \\
\text { book, Instagram), } \\
\text { banner }\end{array}$ \\
\hline Raffi & Book & M & 42 & None \\
\hline Widya & Fashion & F & 29 & $\begin{array}{l}\text { Social Media (Face- } \\
\text { book, Instagram), Fly- } \\
\text { ers }\end{array}$ \\
\hline
\end{tabular}

Based on the in-depth interview, some informants incurred high expenses in sales and occupancy rate. Especially for promotion. Two informants (Dyca and Widya) promotes their store through social media, banner, and flyers to attract consumers to visit their store. Meanwhile, one informants (Raffi) who has run his business for more than 10 years, doesn't promote his store anymore. Raffi depends on his loyal customer and the existing customer who approach his store.

Table 2. Demographic Characteristics of Visitors

\begin{tabular}{|l|l|l|l|l|}
\hline Informant & Sex/Age & $\begin{array}{l}\text { Marital } \\
\text { Status }\end{array}$ & Occupation & $\begin{array}{l}\text { Frequency } \\
\text { in visiting } \\
\text { mall }\end{array}$ \\
\hline Dian & F/24 & Single & Staff & $\begin{array}{l}2-3 \text { times a } \\
\text { week }\end{array}$ \\
\hline Luluk & F/30 & $\begin{array}{l}\text { Married } \\
\text { with 1 } \\
\text { child }\end{array}$ & Entrepreneur & $\begin{array}{l}2-3 \text { times a } \\
\text { week }\end{array}$ \\
\hline Sulaeman & M/38 & $\begin{array}{l}\text { Married } \\
\text { with 1 } \\
\text { child }\end{array}$ & $\begin{array}{l}\text { Civil Gov- } \\
\text { ernment } \\
\text { Service } \\
\text { Officer }\end{array}$ & $\begin{array}{l}1-2 \text { times a } \\
\text { week }\end{array}$ \\
\hline Rina & F/25 & Single & Staff & $\begin{array}{l}3-4 \text { times a } \\
\text { week }\end{array}$ \\
\hline Dita & F/19 & Single & Student & $\begin{array}{l}2-3 \text { times a } \\
\text { week }\end{array}$ \\
\hline
\end{tabular}

On the other side, visitors have different insight regarding wifi as promotional strategy. Informants come from different background, age, sex, status, occupation etc have various behaviour scheme. Table 3 below shows visitor's behaviour related to their motivation in visiting and accessing internet at shopping mall.
Table 3. Visitor's behaviour at Shopping Mall

\begin{tabular}{|c|c|c|c|c|}
\hline $\begin{array}{l}\text { Inform- } \\
\text { ant }\end{array}$ & $\begin{array}{l}\text { Motiva- } \\
\text { tion in } \\
\text { visiting } \\
\text { mall }\end{array}$ & $\begin{array}{l}\text { Reason } \\
\text { looking } \\
\text { for Wifi }\end{array}$ & $\begin{array}{l}\text { Reason Ac- } \\
\text { cessing In- } \\
\text { ternet }\end{array}$ & $\begin{array}{l}\text { Specific } \\
\text { Place } \\
\text { ex- } \\
\text { pected } \\
\text { to have } \\
\text { Wifi } \\
\end{array}$ \\
\hline Dian & $\begin{array}{l}\text { Hangout } \\
\text { with } \\
\text { friends, } \\
\text { Watching } \\
\text { movie, } \\
\text { windows } \\
\text { shopping }\end{array}$ & $\begin{array}{l}\text { Bad con- } \\
\text { nection, } \\
\text { no signal }\end{array}$ & $\begin{array}{l}\text { Ordering } \\
\text { online } \\
\text { transporta- } \\
\text { tion, mes- } \\
\text { senger }\end{array}$ & $\begin{array}{l}\text { Café, } \\
\text { food } \\
\text { court, } \\
\text { lobby }\end{array}$ \\
\hline Luluk & $\begin{array}{l}\text { Monthly } \\
\text { shopping, } \\
\text { quality } \\
\text { time with } \\
\text { family }\end{array}$ & $\begin{array}{l}\text { Slow data } \\
\text { connec- } \\
\text { tion }\end{array}$ & $\begin{array}{l}\text { Taking care } \\
\text { of fuzzy } \\
\text { children } \\
\text { when eating }\end{array}$ & $\begin{array}{l}\text { Food } \\
\text { court, } \\
\text { restau- } \\
\text { rant }\end{array}$ \\
\hline Sulaeman & $\begin{array}{l}\text { visiting } \\
\text { kids play- } \\
\text { ground } \\
\text { with fam- } \\
\text { ily, win- } \\
\text { dow shop- } \\
\text { ping }\end{array}$ & No signal & $\begin{array}{l}\text { Browsing } \\
\text { product } \\
\text { online, com- } \\
\text { paring real } \\
\text { product to } \\
\text { online }\end{array}$ & $\begin{array}{l}\text { Lower } \\
\text { ground } \\
\text { mall }\end{array}$ \\
\hline Rina & $\begin{array}{l}\text { Meeting } \\
\text { with cli- } \\
\text { ent, look- } \\
\text { ing for } \\
\text { café } \\
\end{array}$ & $\begin{array}{l}\text { Have no } \\
\text { internet } \\
\text { connec- } \\
\text { tion }\end{array}$ & $\begin{array}{l}\text { Accessing } \\
\text { documents } \\
\text { for meeting, } \\
\text { messenger }\end{array}$ & $\begin{array}{l}\text { Café, } \\
\text { restau- } \\
\text { rant }\end{array}$ \\
\hline Dita & $\begin{array}{l}\text { Hangout } \\
\text { with } \\
\text { friends, } \\
\text { family } \\
\text { time } \\
\end{array}$ & $\begin{array}{l}\text { No pack- } \\
\text { age data }\end{array}$ & $\begin{array}{l}\text { Download- } \\
\text { ing mov- } \\
\text { ie/music, } \\
\text { social media }\end{array}$ & $\begin{array}{l}\text { Lobby, } \\
\text { food } \\
\text { court, } \\
\text { cafe }\end{array}$ \\
\hline
\end{tabular}

Visitors shared same problem dealing with wifi configuration system in an attempt to access the internet at shopping mall. The second problem related to the helpdesk officer who considered incompatible in dealing with this problem. Therefore, unless visitors have good signal and own data connection, wifi is considered as unimportant at shopping mall.

Different demographic characteristics shows different behaviour related to their motivation in accessing wifi at shopping mall.

\subsection{Wifi Marketing Readiness for Tenants}

Technology readiness index [31] refers to people's propensity to embrace and use new technologies for accomplishing goals in home life and at work. This technology readiness becomes driver for enablement of new technology that have benefit for people.

Tenants show high optimism and positive attitudes towards wifi-marketing, we asked informants to rate the importance of wifi at shopping mall and their likelihood to use wifi for promotional purpose is strong. as Dyca stated in the interview that

"it would be great idea for me because our customer is actually the ones at the mall, not those who are far away from shopping mall." 
Besides that, wifi marketing considered to be great innovation for mall especially for tenants who are temporary run their business at mall, like Widya who actively engaged in mall's event.

"for me, it's been challenging and frustrating to attract customer. It feels like a messy market, too many people come and go to our store, it feels like we depends on their impulsiveness, I believe that any technology that boost our promotion would be good"

Optimism relates to a positive view of technology and a belief that technology offers people some benefit. In terms of reducing sales expenses is the most highlight benefit for the existence of wifi marketing. However, new technology faces constraint in adoption process. Discomfort possibly occurred for tenants, like Widya said that

"we paid bucks to be part of this mall, if I have to spend more money on that promotion, I will think twice before I use it, so far I get used to social media and I'm okay with it"

The current promotion strategy and the uncertainty over control towards wifi-marketing have become discomfort towards tenants to adopt wifi for promotion strategy. The other tenants (Dyca) added that

"I doubt that it will be free from management office, If I should pay, I prefer having a trial for 1-2 months to see that it works as expected. Because I'm not sure whether it will be effective than any other promotion media I used like facebook or instagram"

Meanwhile, high discomfort and insecurity come from Raffi who has no interest in adopting wifi as new technological advancement at shopping mall,

"No need. People come to my shop is certain that they are looking for books. I don't need to promote because I have already had their contact, every time they need book, they just message me via phone"

The insecurity arises towards the system preference and skepticism that wifi-marketing will work properly. Besides that, the overwhelmed feeling towards current promotional strategy. However, the more business owner adopted technology for promotion like social media, the higher possibility to adopt wifi for promotional purpose.

\subsection{Wifi Marketing Readiness for Visitors}

Visitors shows high interest for wifi-marketing. Most of the informants are technology literate and categorized as active user for smartphone. they show their optimism and innovativeness traits since they have high awareness on the term of "wifi" and "promotion", as Dian said

"It's very important for mall to have wifi around the corner, because sometimes the connection is quite bad when I'm in mall. Especially when I need to activate my messanger to contact my friends"

She added that

"I will need that! It helps me looking for sales and special offers easily. I would also prefer some recommendation of new store and restaurant. If it could do both. I'd love to use that"

Somehow, Sulaeman stated different insight on wifi marketing as he said that

"I rarely look for wifi unless there's no signal in the mall like in lower ground floor. But I usually check and compare the products that we would like to buy online. So, I don't need some promotions because I already know what I have to buy."

Based on demographic traits, female informants are more attracted to wifi marketing in the sense that it can provide some information about discount and promotions. Meanwhile, male informants shows more discomfort and insecurity towards the system. Man is more rational buyer than woman [cari jurnalnya]

Another female informants also shows their optimism towards wifi-marketing,

"I go to mall 3-4 times a week for a meeting my colleagues or clients. I need café/restaurant that provide me with strong wifi. It would be better if wifi can cover every corner of the mall so I don't need to be picky on where to eat. Wifi is always my top priority everytime I have lunch/dinner for meeting purpose, If there's technology that would recommend me nice place to eat, that's nice!'-Rina

"I always have my mifi (mobile wifi) with me, sometime it didn't get signal, I try to look for any wifi available. I need it because my daughter is very fussy. I need to access youtube to calm her down. It's the best way to have a peaceful dining with your family"-Luluk

In other hand, female informants shows their discomfort and insecurity by showing their concern on privacy issue, as Dita said

"I prefer free access wifi without disclosing my personal information like mobile phone or social media account, I don't want to received random invitation in my account".

Although there are some discomfort and insecurity towards adopting wifi, women informants tend to show positive attitudes towards wifi-marketing.

\subsection{Design Needs for Wifi Marketing}

By using ethnography approach, this research attempts to explore the native's point-of-view in a holistic manners which can provide a unique perspective to understand user's activities. It is important stage to enable developer of wifi-marketing at better suited to the needs of the users.

Based on the observation and interview, researcher aims to understand the environment in which tenants and visitors are doing. In fact, there are some problem that have been experienced by visitors regarding to the current condition of mall. Visitor's have issue with looking for tenant's location, various types of tenants, difficulties in acknowledging new tenants, and the availability of helpful helpdesk.

Welcome page is the interface that appear in the first attempt to have wifi access. Based on the problem above, the welcome page should cover some information as follow:

a. Mall's directory (tenant, facility, etc)

b. Discount and special offering from tenants

c. Recommendation for café or restaurant

d. New tenant introduction

e. Customer service

Meanwhile, for tenants, developer should consider the demographic characteristics as one of factors that could affect technology readiness among tenants [32]. The findings are suggested as the exploration of design needs that meet 
with some characteristics and features on the development of wifi marketing.

Wifi-marketing readiness for tenants and visitors is a new aspect of technology that try to understand the well-established assessment based on user's perspective and environment. Tenants and Visitors shows high desire for wifi marketing however different demographical traits have impact on customer's optimism, innovativeness, discomfort and insecurity.

\section{Conclusion}

This research explored the design needs for wifi-marketing. This research addressed technology readiness and co-design artifacts of welcome page for wifi-marketing. There are some consideration for tenants and visitors as the major end-user for this technology. From tenants' point-of-view, the type of business, product sold, promotion strategy and user's learning process have been concerns for developer to engage well with the tenants. Meanwhile, from visitors' point-of-view, their motivation, shopping pattern and demographical traits reflect their attitudes towards wifi-marketing.

Moreover, the design of wifi-marketing that meet tenants' and visitor needs must consider the tenant's location, promo and special offering, new tenants information, restaurant recommendation.

This research is the first stage or preliminary research for the exploratory framework of technology acceptance model of wifi-marketing. In the future, there's a need to explore on the examination of the adoption of wifi-marketing for shopping mall.

\section{ACKNOWLEDGEMENT(S)}

The authors would like to thank Product Development Unit of Wifi.Id Commercial at PT. Telkom for assisting this research with tremendous support. Moreover, For all informants in this research for valuable time and support.

\section{REFERENCES}

[1] Jakarta Globe. (2013). Governor Joko Extends Mall Moratorium. [online]. Available: http://jakartaglobe.id/news/jakarta/governor-joko-extends-ja karta-mall-moratorium/

[2] CNN Indonesia. (2016). Tingkat Hunian Mal di Jakarta Turun di Akhir Tahun. [online]. Available: http://marketeers.com/rapot-pengembangan-mal-pada-2016/

[3] Al Hafiz, M.P. (2017). Pengembangan Mal di Jakarta Hanya Tumbuh Tipis. [online]. Available : http://marketeers.com/rapot-pengembangan-mal-pada-2016/

[4] KBRI Seoul. (2015). Kelas Menengah di Indonesia Mencapai 170 Juta Pada Tahun 2015. [online]. Available : http://kbriseoul.kr/kbriseoul/index.php/id/2013-01-21-22-4905/berita-terkini/419-kelas-menengah-di-indonesia-mencapa i-170-juta-pada-tahun-2015
[5] Ravallion, M. (2010). The Developing World's Bulging (but Vulnerable) Middle Class. World Development, 38(4), 445-454

[6] Deloitte. (2015). Deloittle Consumer Insights : Capturing Indonesia's Latent Markets. [pdf]. Avalilable : https://www2.deloitte.com/content/dam/Deloitte/jp/Docume nts/consumer-business/cp/jp-cp-middle-class-indonesia-en.p df

[7] SWAOnline. (2016). Memahami Perilaku Belanja Online. Available https://swa.co.id/swa/my-article/memahami-perilaku-belanja -online

[8] Das, G., and Varshneya, G. (2017). Consumer Emotions: Determinants and Outcomes in Shopping Mall. Journal of Retailing and Consumer Services 38(2017) 177-185

[9] Oosterlinck, D., Benoit, D.F., Baecke, P., Van de Weghe, N. (2017). Bluetooth Tracking of Humans in an Indoor Environment: An Application to Shopping Malls Visits. Applied Geography 78 (2017) 55-65

[10] Seftyanti, E.P. (2014). Pacific Place menjadi Mall Pertama di Asia Pasifik yang Menggunakan Teknologi Bluetooth Beacon. Available

at https://id.techinasia.com/pacific-place-mall-gunakan-teknolo gi-bluetooth-beacon-aplikasi-pacific-place-mal

[11] Duha, H.R. dan Sembiring, E.B. (2016). Aplikasi Rute dan Informasi Mall Berbasis Android. Teknomatika Vol. 8 No. 2 Januari 2016

[12] Hulme, G. (2001). Certicom targets wireless market. Information Week

[13] The Kiplinger Letter. (2002). vol. 79, no. 49 (December 6).

[14] The Kiplinger Letter. (2003). vol. 80, no. 16 (April 17).

[15] Gillott, I. (2002). The ROI benefits of wireless. Communications News,

[16] Munro, N. (2002). Internet without the wires. National Journal, 34(19)

[17] Wi sphere. (2017). Wifi Marketing Experiencies. Available at https://wifimarketing.net

[18] Md. Zainal Abedin \& Laboni Ferdous. (2015). Promotional Strategies of Telecommunication Industries and Customers Perception: A Study on Airtel Bangladesh Limited. Global Journal of Management and Business Research: E Marketing Volume 15 Issue 3 Version 1.0 Year 2015

[19] Gary R. Schornack, Charles E.Beck (2004) Wireless Technologies for Marketing And Management Professionals. Journal of Applied Business Research (JABR), vol 20 no.4

[20] Asikhia, O.U. (2000). Promotion Management: Principles \& Practice. Lagos: Bimsmat Venture Limited

[21] Timothy R. Graeff, (1995),"Product comprehension and promotional strategies", Journal of Consumer Marketing, Vol. 12 Iss 2 pp. 28 - 39

[22] Adesoga Dada Adefulu. (2015). Promotional Strategy Impacts on Organizational Market Share and Profitability. ACTA Universitatis Danubius Vol 11, no 6, 2015

[23] Burton-Jones, Andrew and Hubona, Geoffrey S. (2006). The mediation of external variables in the technology acceptance model. Information and Management vol. 43 issue $6 \mathrm{pp}$. 706-717 
[24] Venkatesh, V., \& Davis, F. D. (2000). A theoretical extension of the technology acceptance model: Four longitudinal field studies. Management Science, 46, 186-204.

[25] Parasuraman, A. (2000). Technology Readiness Index (TRI) a Multiple-item scale to measure readiness to embrace new technologies. Journal of Service Research 2(4). 307-320

[26] Erdog mus, N., and Esen, M. (2011). An Investigation of the Effects of Technology Readiness on Technology Acceptance in e-HRM. Procedia Social and Behavioral Sciences 24(2011) $487-495$

[27] Chien-Hsin Lin, Hsin-Yu Shih, and Peter J. Sher (2007). Integrating Technology Readiness into Technology Acceptance: The TRAM Model. Psychology \& Marketing, Vol. 24(7): 641-657

[28] Insitu. (2016). What is Design Ethnography. Center for Socially Engaged Design University of Michigan

[29] Aboelmaged, M.G. (2014). Predicting e-readiness at firm level: An Analysis of Technological, organizational and Environmental (TOE) effects on e-maintenance readiness in manufacturing firms

[30] Viswanathan, M., Rosa, J. A., and Ruth, J.A. (2010). Exchanges in Marketing Systems: The Case of Subsistence Consumer-Merchants in Chennai, India. Journal of Marketing 74(3) page. 1-17

[31] Tsourela, M., and Roumeliotis, M. (2015). The Moderating Role of Technology Readiness, Gender, and Sex in Consumer Acceptance and Actual Use of Technology-based services. Journal of High Technology Management Research

[32] Abbasi, M.S., Tarhini, A., Hassouna, M., Shah, F. (2015). Social, Organizational, Demography, and Individuals' Technology Acceptance Behaviour: A Conceptual Model. European Scientific Journal March 2015 vo. 11 No. 9 page $1857-1881$ 